\title{
勉县抗旱应急水源工程建设主要做法和效益分析
}

\author{
周坪 张伟妮 \\ 陕西省勉县水利局 \\ DOI:10.32629/hwr.v4i7.3212
}

\begin{abstract}
[摘 要] 干旱灾害是影响勉县经济社会发展的主要自然灾害之一, 通过实施抗旱应急水源工程建设, 提 高抗旱应急能力。本文介绍了勉县抗旱应急水源工程建设总体情况、主要做法, 论述了已建成项目在精 准扶贫、抗旱应急供水等方面取得的显著效益和运行管护工作, 为今后实施同类型项目提供了指导, 提出 了下一步的工作建议。
\end{abstract}

[关键词] 抗旱应急水源工程; 做法; 效益

勉县位于汉中盆地西端, 东西宽 57.6 公里, 南北长82.5 公里, 土地总面积 2406 平方公里, 其中平川面积占 $8.8 \%$, 丘 陵占 $16.4 \%$, 山区占 $74.8 \%$, 辖 17 个镇, 1 个 街道办, 198 个行政村 (社区), 总人口 43 万人, 干旱灾害是影响勉县经济社会发 展的主要自然灾害之一, 对群众生活、工 农业生产和生态环境影响严重。勉县“十 年九旱”, 资源型缺水和工程性缺水并存, 尤其是抗旱应急水源十分匮乏, 在中省 市水利等部门关心支持下, 勉县被列入 陕西省2014年-2016年抗旱规划实施方 案范围内, 通过实施抗旱应急水源工程 建设, 提高抗旱应急能力。省市水利部门 共计下达勉县2014-2016年抗旱应急水 源工程 4 个年度项目共 13 子项, 总投资 2741.18 万元, 其中中央投资 2178 万元, 地方配套 563.18 万元。截止目前, 勉县抗 旱应急水源工程 4 个年度项目全部建成 投用。

\section{1 领导重视,强力推进}

勉县各级高度重视抗旱应急水源 项目实施工作, 县政府每年与相关镇 (街道办) 签订年度项目建设目标责任 书, 进一步落实基层政府抗旱应急水源 项目实施的主体责任。每年初召开专题 会议作出安排部署。成立了由县政府分 管副县长为组长, 各有关镇、部门为成 员的勉县抗旱应急水源工程建设领导 小组, 明确了工作职责和具体任务, 形 成推进抗旱应急水源工程建设的强大
合力。勉县人民政府批准组建了勉县抗 旱应急水源工程项目管理办公室作为 勉县抗旱应急水源工程建设的项目法 人, 具体负责勉县抗旱应急水源工程项 目组织实施工作。县政府主要领导和分 管领导多次深入施工现场, 检查指导协 调工程建设。县水利局和防汛办抽调精 锐力量, 负责工程建设管理工作, 有力 促进了工程顺利建设。

\section{2 严格管理,确保质量}

2. 1 认真组织, 严格落实项目管理各 项制度

按照省市相关要求, 按时编制和上 报了项目建设实施方案。根据上级批复, 我们严格按照《陕西省抗旱应急水源工 程项目建设与资金管理实施办法》组织 实施, 以年度项目实行打捆方式公开招 标, 确定了施工单位和监理单位。在项目 实施过程中, 严格落实了项目法人制、招 投标制、监理制、合同制等基本建设项 目各项制度, 从而确保了项目建设管理、 质量、进度、资金、生产安全各项目标 的顺利实现。

2.2加强监管, 确保工程建设质量

一是项目办、设计、施工及监理单 位按照相关规定, 建立健全了工程质量 保证、安全管理和监督制度体系, 同时项 目办与质量监督部门签订了质量监督书, 强化了质量监督。二是严格质量检查。 项目办对每个项目都落实了管理人员, 采取平行检查和旁站监理等方式监督检
查工程质量, 主要领导和分管领导不定 期深入工地检查, 确保了工程质量; 三是 严格落实责任。实行从监理人员、项目 办现场管理人员、工程技术负责人、项 目办负责人到主管领导一级对一级负责 的管理制定, 落实了质量责任; 五是严把 工程验收关。对上一道工序验收不合格 的不允许开展下一道工序施工, 对达不 到质量标准的坚决不予验收和资金兑付, 对已经验收的工程, 实行质量保证金制 度, 保证了工程质量。

2. 3严格管理, 确保工程资金安全

严格执行《陕西省抗旱应急水源工 程项目建设与资金管理实施办法》的规 定进行项目资金管理, 一是财政部门主 动参与到工程建设管理中, 掌握工程建 设动态, 及时拨付工程资金; 二是严格实 行财政资金集中支付; 三是对工程资金 建立专帐、落实专人进行管理; 四是严 格进行资金控制, 按照工程完成进度情 况支付工程款项; 五是对工程资金支付 采取发票会签制度, 在工程支出票据上, 从现场技术人员、技术负责人、建设单 位负责人、主管领导到主要领导必须同 时签字后方可作为有效支出, 从而规范 了工程建设资金的管理。

3 超前谋划, 积极争取, 提前实 现了项目建设目标

一是武侯集镇和勉县第一中学人饮 应急水源工程属于 2016 年度项目, 由于 近几年干旱影响, 加之勉县第一中学招 
生规模扩大, 导致供水水源非常紧张, 原 来使用的自备抽水机井出水量逐年减少, 水源地污染难以解决, 加之学校所在地 武侯镇被列入陕西省旅游名镇进行开发 建设, 用水量激增。2015年4月由于勉县 第一中学缺水, 导致学生集体腹泻, 造成 不良社会影响。按照县委、县政府的要 求, 提前开展了项目前期工作, 积极向省 市主管部门汇报争取, 在省市主管部门 领导的关心支持下, 超前审批, 把 2016 年 度项目提前到2015年实施。为了赶在春 季开学前向勉第一中学供水, 周密计划, 倒排工期, 增加机械人力, 春节仅仅停工 10 天, 终于在 3 月 7 日正式向第一中学供 水, 彻底解决了困扰勉县第一中学十多 年的用水难题, 得到了师生及家长的好 评。二是阜川镇虽然是勉县的暴雨中心, 水资源丰富, 但是人饮供水要么水源不 足, 要么水质不好, 一直是困扰区域经济 发展的一个难题。勉县提前谋划, 完成了 勉县阜川镇抗旱应急供水项目设计工作, 项目实施条件成熟, 2016年, 多次赴省市 主管部门汇报争取, 省市水利部门同意 把勉县皁川镇抗旱应急供水工程增补到 2016年抗旱应急水源工程范围进行实 施。通过该项目的实施, 可以解决阜川镇 集镇及沿线 11 个村 1.37 万人的饮水问题, 为区域经济快速发展和顺利完成脱贫工 作打下坚实的基础。

\section{4 强化运行管理, 确保效益长 久发挥}

勉县抗旱应急水源工程全部落实了 建后管护主体和责任, 建立了运行机制,
落实了管理经费。工程所在地有水管单 位的由所在辖区水管单位进行管护和 运行, 没有水管单位的由所在受益镇、 村成立管理机构进行管护和运行。实现 由 “建设管理” 向 “运行管护” 转变, 做到“建成一处、运行一处、见效一处”。 勉县2014-2016年抗旱应急水源工程 共计实施完成项目 13 个, 项目建成后, 保证了 1.5 万亩基本口粮田在干旱期灌 溉用水需求, 保障了 5.4 万人在干旱期 基本生活用水及常规用水, 涉及 30 个建 档立卡扶贫村 0.71 万亩基本口粮田在 干旱期灌溉用水需求, 保障了 12 个贫困 村 1.39 万人在干旱期基本生活用水。总 体来看, 勉县抗旱应急水源工程的实施, 项目区抗旱应急能力得到显著提高, 不 仅有效缓解了项目区群众因旱缺水的 困难状况, 解决了贫困村群众多年期盼 的旱期饮水安全问题, 还对项目区群众 脱贫提供了有力支撑, 为区域经济社会 协调发展奠定了坚实的基础, 取得了较 好的社会效益。

\section{5 建议}

虽然勉县抗旱应急水源工程建设工 作取得了一定成绩, 但也存在着抗旱应 急基础设施薄弱的问题。建议: 一是勉 县将在省市业务部门的精心指导下, 严 格执行项目管理各项规定, 进一步夯实 责任, 再添措施, 强化管理, 追赶超越, 确 保项目按期完成, 落实管护责任和制度, 确保项目长期发挥效益。二是争取早日 再次启动抗旱应急水源工程。通过实施 2014-2016年抗旱应急水源工程, 项目区
干部群众十分欢迎, 热切期盼加大建设 力度。基层干部群众纷纷反映抗旱应急 水源工程定位准确、保障目标明确、效 益十分明显, 解决了当前旱区群众燃 眉 之急, 迫切希望继续实施。建议国家尽早 再次启动实施抗旱应急水源工程建设, 通过兴建应急水源工程, 解群众饮水、抗 旱浇地之困, 为旱区和贫困区群众造福。 三是尽早启动抗旱非工程措施项目建 设。建议国家组织开展抗旱非工程措施 建设技术指标体系研究, 组织编制全国 抗旱非工程措施实施方案, 试点开展非 工程措施建设, 给予资金、政策支持和技 术指导。

\section{[参考文献]}

[1]国务院办公厅. 关于加强抗旱工 作的通知(国办发[2007]68 号)[R],2007.

[2]水利部, 国家发改委, 财政部, 等. 关 于印发全国抗旱规划实施方案 (2014-2016 年) 的通知 (水汛 [2014] 300 号) [R], 2014.

[3]杨光, 刘宝军, 贾汀. 全国抗旱规 划实施工作思考与启示[J].中国防汛抗 旱,2016,26(2):7-10+14.

[4]吕石生, 刘燕龙. 湖南省引调 提水工程建设经验 [J]. 中国防汛抗 旱,2017,24(4):9-11+14.

[5]朱建海, 姬跃红, 曹希英, 等.甘肃 省实施抗旱规划的经验及建议[J]. 中国 防汛抗旱,2015,25(2):13-14+25.

[6]翟大明,黄喜峰.陕西省抗旱应急 水源工程实施效益与工作启示[J].中国 防汛抗旱,2017,27(4):1-3+27. 